\title{
Spatial-temporal Variation and Local Source Identification of Air Pollutants in a Semi-urban Settlement in Nigeria Using Low-cost Sensors
}

\author{
Oyediran Kayode Owoade ${ }^{1}$, Pelumi Olaitan Abiodun ${ }^{1}$, \\ Opeyemi R. Omokungbe ${ }^{1}$, Olusegun Gabriel Fawole ${ }^{1,2}$, \\ Felix Samuel Olise ${ }^{1}$, Olalekan O.M. Popoola ${ }^{3}$, Roderic L. Jones ${ }^{3}$, \\ Philip K. Hopke ${ }^{4,5^{*}}$
}

\author{
${ }^{1}$ Environmental Pollution Laboratory, Department of Physics and Engineering Physics, Obafemi \\ Awolowo University, Ile-Ife, Nigeria \\ ${ }^{2}$ Atmospheric Science Unit, Department of Environmental Sciences, Stockholm University, \\ Stockholm, Sweden \\ ${ }^{3}$ Department of Chemistry, University of Cambridge, Cambridge, UK \\ ${ }^{4}$ Institute for a Sustainable Environment, Clarkson University, Potsdam, NY, USA \\ ${ }^{5}$ Department of Public Health Sciences, University of Rochester School of Medicine and \\ Dentistry, Rochester, NY, USA
}

\section{ABSTRACT}

Low-cost sensors were deployed at five locations in a growing, semi-urban settlement in southwest Nigeria between June 8 and July 31, 2018 to measure particulate matter $\left(\mathrm{PM}_{2.5}\right.$ and $\mathrm{PM}_{10}$ ), gaseous pollutants ( $\mathrm{CO}, \mathrm{NO}, \mathrm{NO}_{2}, \mathrm{O}_{3}$ and $\mathrm{CO}_{2}$ ), and meteorological variables (air temperature, relative humidity, wind speed and wind-direction). The spatial and temporal variations of measured pollutants were determined, and the probable sources of pollutants were inferred using conditional bivariate probability function (CBPF). Hourly $\mathrm{PM}_{2.5}$ and $\mathrm{PM}_{10}$ concentrations ranged from $20.7 \pm$ 0.7 to $36.3 \pm 1.6 \mu \mathrm{g} \mathrm{m}^{-3}$ and $47.5 \pm 1.5$ to $102.9 \pm 5.6 \mu \mathrm{g} \mathrm{m}^{-3}$, respectively. Hourly gaseous pollutant concentrations ranged from $348 \pm 132$ to $542 \pm 200 \mathrm{ppb} \mathrm{CO}, 21.5 \pm 7.2 \mathrm{ppb} \mathrm{NO}$ and $57.5 \pm 11.3$

\section{OPEN ACCESS}

Received: October 19, 2020

Revised: July 11, 2021

Accepted: July 18, 2021

${ }^{*}$ Corresponding Author:
phopke@clarkson.edu

\section{Publisher:}

Taiwan Association for Aerosol Research

ISSN: $1680-8584$ print

ISSN: 2071-1409 online

Copyright: The Author(s). This is an open access article distributed under the terms of the Creative Commons Attribution License (CC BY 4.0), which permits unrestricted use, distribution, and reproduction in any medium, provided the original author and source are cited. differences in the hourly-average pollutant concentrations. Diel variation analyses indicated that $\mathrm{CO}_{2}, \mathrm{PM}_{2.5}$, and $\mathrm{PM}_{10}$ peaked in the early hours of most days, $\mathrm{O}_{3}$ at noon while $\mathrm{NO}, \mathrm{NO}_{2}$, and $\mathrm{CO}$ peaked in the evening. Most pollutants were of anthropogenic origins and exhibited the highest contributions from the southwest at most sampling locations. There were strong similarities between pollutants source contribution at two of the monitoring sites that were in residential areas with a frequently used paved road. Mitigation strategies need to be established to avoid further deterioration of ambient air quality that negatively affect public health.

Keywords: Temporal variation, Low-cost sensors, Particulate matter, CBPF, Source identification

\section{INTRODUCTION}

Environmental degradation is a major consequence of increasing population, economic development, rapid industrialization, and technological advancement (Morais et al., 2012; Mohsin et al., 2019). Air pollution is a well-known global problem in developed and developing nations due to its effects on public health and the environment at local, regional, and continental scales. Air pollution heightens the risk of respiratory and cardiovascular diseases, lowers the survival rates in the newborns, reduces the life expectancy of people with existing health issues, and produces acute effects on the exposed population (Dockery et al., 1993; Dockery and Pope, 1994; Pope, 2000). Clean air is a basic requirement for human comfort, health, and well-being and is being 
affected by air pollution, leading to human morbidity and mortality. Environmental issues such as acid rain, visibility impairment, alteration of the atmospheric radiation budget, and modification of cloud properties are also adverse effects of air pollution (Owoade et al., 2012; Tian et al., 2014). Air pollutants have been studied from both human and environmental health perspectives. Regulatory and advisory bodies such as the United States Environmental Protection Agency (U.S. EPA) and the World Health Organization (WHO) have established standards/guidelines for daily and annual concentrations of the different air pollutants. However, these values are exceeded in many locations.

Air pollutants may arise from natural or anthropogenic sources, and they can be transported over long distances, crossing both local and international boundaries (Owoade et al., 2012; Fawole et al., 2016). The major atmospheric pollutants include sulfur dioxide $\left(\mathrm{SO}_{2}\right)$, oxides of nitrogen $\left(\mathrm{NO} / \mathrm{NO}_{2} / \mathrm{NO}_{x}\right)$, ozone $\left(\mathrm{O}_{3}\right)$, oxides of carbon $\left(\mathrm{CO} / \mathrm{CO}_{2}\right)$ and particulate matter (PM). PM is particularly important because of its variable chemical composition, size, morphology, frequent occurrences of high concentrations, and its significant effects on human health and the environment (Sumesh et al., 2017). Ozone is formed in the troposphere through photochemical reaction of $\mathrm{NO}_{\mathrm{x}}$ and volatile organic compounds (VOCs) (Seinfeld and Pandis, 2016). Significant sources of $\mathrm{NO}$ in urban settings are motor vehicles and power generation systems (Ul-Haq et al., 2015). NO is primarily emitted as $\mathrm{NO}$ with a smaller proportion of $\mathrm{NO}_{2}$. However, the reaction with $\mathrm{O}_{3}$ rapidly converts $\mathrm{NO}$ to $\mathrm{NO}_{2}$. The $\mathrm{CO}$ concentrations found in the lower atmosphere are typically associated with incomplete combustion activities as well as the oxidation of atmospheric methane.

In addition to the variable strength of the emission sources, variations in air pollutant concentrations are associated with the meteorological conditions, local environmental properties (land area, size, vegetation cover and population), and the availability of other pollutant precursors (Khiem et al., 2010; Wang et al., 2018). Notable spatial and temporal variations have been found for $\mathrm{CO}$ within the boundary layer up to scales of high inter hemispheric gradients (Yashiro et al., 2009). PM concentrations at any location vary with the local source strengths and other processes such as atmospheric chemical reactions, deposition, precipitation, and new particle formation (Sumesh et al., 2017). Hu et al. (2018) and Zhang and Jiang (2018) reported that local emission sources and potential effects of meteorology at meso - and synoptic scales might influence PM concentrations. The mixing layer depth and local weather dynamics drive the dispersion of source emissions at local scales while long-range transport affects the movement of PM over regional, transboundary, and continental scales. Multiple authors (Owoade et al., 2012; Guttikunda and Gurjar, 2012; Jayamurugan et al., 2013; Cheng et al., 2013; Gogikar and Tyagi, 2016; Gogikar et al., 2018) reported that meteorological variables such as wind speed and direction, air temperature, relative humidity, and rainfall govern the advection and dispersion of pollutants in any region.

A major challenge in monitoring air pollutant concentrations across an area and the influence of meteorology is the availability of measurement instruments. Most federal reference method (FRM or research grade) instruments are costly and difficult to move because of their size, power requirements, and ancillary systems such as sampling manifolds. Thus, they are typically stationed in fixed locations (Karagulian et al., 2019). Data obtained from the FRMs yield limited information on spatial variations of pollutants. Recent improvements in micro-technology have led to the development of portable monitoring systems for particulate matter and gaseous pollutants. These monitors are low-cost, very mobile, and can be deployed indoors and outdoors (Kumar et al., 2015; Sousan et al., 2016; Manikonda et al., 2016; Zikova et al., 2018; Crilley et al., 2018; Masiol et al., 2018; Li et al., 2020).

Existing studies of particulate air pollution in this area of lle-Ife, Nigeria focused on the elemental characterization and receptor modeling to identify the likely particulate pollutant sources (Ogundele et al., 2016; 2017; Owoade et al., 2015). The only major point source in the area is a scrap steel and iron smelting facility (Owoade et al., 2015; 2016; Ogundele et al., 2017). Owoade et al. (2016) identified four sources in both the $\mathrm{PM}_{2.5}$ and $\mathrm{PM}_{2.5-10}$ size fractions that were labeled: soil $(44 \%)$, savannah burning (26\%), scrap processing (18\%), and vehicular emissions (12\%) for $\mathrm{PM}_{2.5}$ and soil plus biomass burning (71\%), sea salt (22\%), scrap processing (5\%) and vehicle emissions (including tire wear) (2\%) for $\mathrm{PM}_{2.5-10}$. The biomass burning in the $\mathrm{PM}_{2.5}$ fraction would likely also include cooking emissions that include both the biomass burning for heat and the emitted cooking particles. All of these measurements were made either adjacent to the iron/steel 
facility or on the Obafemi Awolowo University campus. Thus, limited information was available on the PM concentration variability across the area and its influencing factors.

If the temporal and spatial variability and directional characteristics of the pollutants can be determined, they can be employed to identify hot spots, pollutant sources and provide the information needed to implement appropriate mitigation measures. Therefore, this study monitored particulate matter and gaseous pollutants concentrations in lle Ife, Nigeria, analyzed their temporal variations and spatial variability, and provided directional information of their measured concentration using low-cost sensors. Omokungbe et al. (2020) made an initial report of the $\mathrm{PM}_{2.5}$ and $\mathrm{PM}_{10}$ results in which they examined the relationships between the measured PM values with temperature and relative humidity values. Higher PM concentrations were observed at lower temperatures and there was no variation of $\mathrm{PM}$ with $\mathrm{RH}$ when the $\mathrm{RH}<80 \%$. There were effects of $\mathrm{RH}$ for values $>80 \%$ likely due to the hygroscopic growth of the particles above the likely deliquesce relative humidity value. However, detailed spatial and temporal analyses were not made and those analyses and the resulting information about gaseous and particulate pollutions is the focus of this work.

\section{METHODOLOGY}

\subsection{Study Area}

The study was conducted in a fast-growing city, lle-Ife in southwestern Nigeria $\left(7.33^{\circ} \mathrm{N}\right.$ and $4.31^{\circ} \mathrm{E}, 294 \mathrm{~m} \mathrm{A.S.L.).} \mathrm{It} \mathrm{has} \mathrm{an} \mathrm{average} \mathrm{population} \mathrm{of} \mathrm{about} \mathrm{502,000} \mathrm{(NPC,} \mathrm{2006)} \mathrm{that} \mathrm{was}$ projected to have grown to 886,300 . A major road passes through the city with several minor roads (paved and unpaved) linking different parts of the city for the easy movement of vehicles and passengers. The city hosts Obafemi Awolowo University (OAU), Obafemi Awolowo University Teaching Hospital Complex (OAUTHC), and a private polytechnic college. In addition to these institutions, a steel smelting factory is situated on the outskirts of the city along the Ife-Ibadan Expressway. Climatically, it experiences two major seasons (wet and dry). The dry season occurs from November to March the following year while the rainy season runs from April to October. During the dry season, there is little precipitation with high solar radiation, clear sky conditions, and high air temperatures. Cold, dust-laden northeasterly trade winds from the Bodele Depression in the Chad Basin in the Sahara Desert can blow across the region delivering significant quantities of dust for several days. In the wet season, the near surface flow is controlled by southwesterly winds emanating from the Atlantic Ocean and resulting into moderate temperatures and an abundance of rainfall (Falaiye et al., 2013).

\subsection{Air Monitoring}

Gaseous pollutants $\left(\mathrm{CO}, \mathrm{CO}_{2}, \mathrm{NO}, \mathrm{NO}_{2}\right.$, and $\left.\mathrm{O}_{3}\right)$ and size segregated particulate matter fractions $\left(\mathrm{PM}_{2.5}\right.$ and $\mathrm{PM}_{2.5-10}$ ) were monitored using low-cost monitoring sensors in a monitoring package at five locations in Ile Ife, southwestern Nigeria. The sampling locations were distributed across the city and the choices of the location were considered appropriate based on open space and the absence of any obstruction that would hinder the free circulation of air. Three sites (P1, P2 and P3) were located within the Obafemi Awolowo University campus, and two locations (P4 and P5) were within a fast-growing residential area of the city with one location generally downwind of an industrial area situated very close to the busy Ife-Ibadan Expressway. Fig. 1 shows the sampling site locations in the city. The five low-cost sensor packages were simultaneously deployed at all the chosen locations. Each low-cost monitor was placed $3 \mathrm{~m}$ above the ground level. Brief descriptions of each site are presented in Table 1. Air monitoring took place from June till July 2018. The duration was short as this is a preliminary study on air quality research in southwestern Nigeria.

The sensor packages used in this study were AlphaSense low-cost portable air monitoring devices. Optical particle counters (OPC-N2) measured particulate matter while gaseous pollutants were monitored with electrochemical sensors. The OPC sensor records particles per milliseconds in 16 size bins and estimates PM concentrations in the range of 0.38 to 17 microns with a maximum particle count of $10000 \mathrm{~s}^{-1}$ (Crilley et al., 2018). The OPC-N2 converts the particle concentration to mass concentration corresponding to the PM metrics: $\mathrm{PM}_{2.5}$ (for particulate matter $\leq 2.5 \mu \mathrm{m}$ ) and $\mathrm{PM}_{10}$ (for particulate matter $\leq 10 \mu \mathrm{m}$ ). The electrochemical sensors operate on amperometric 


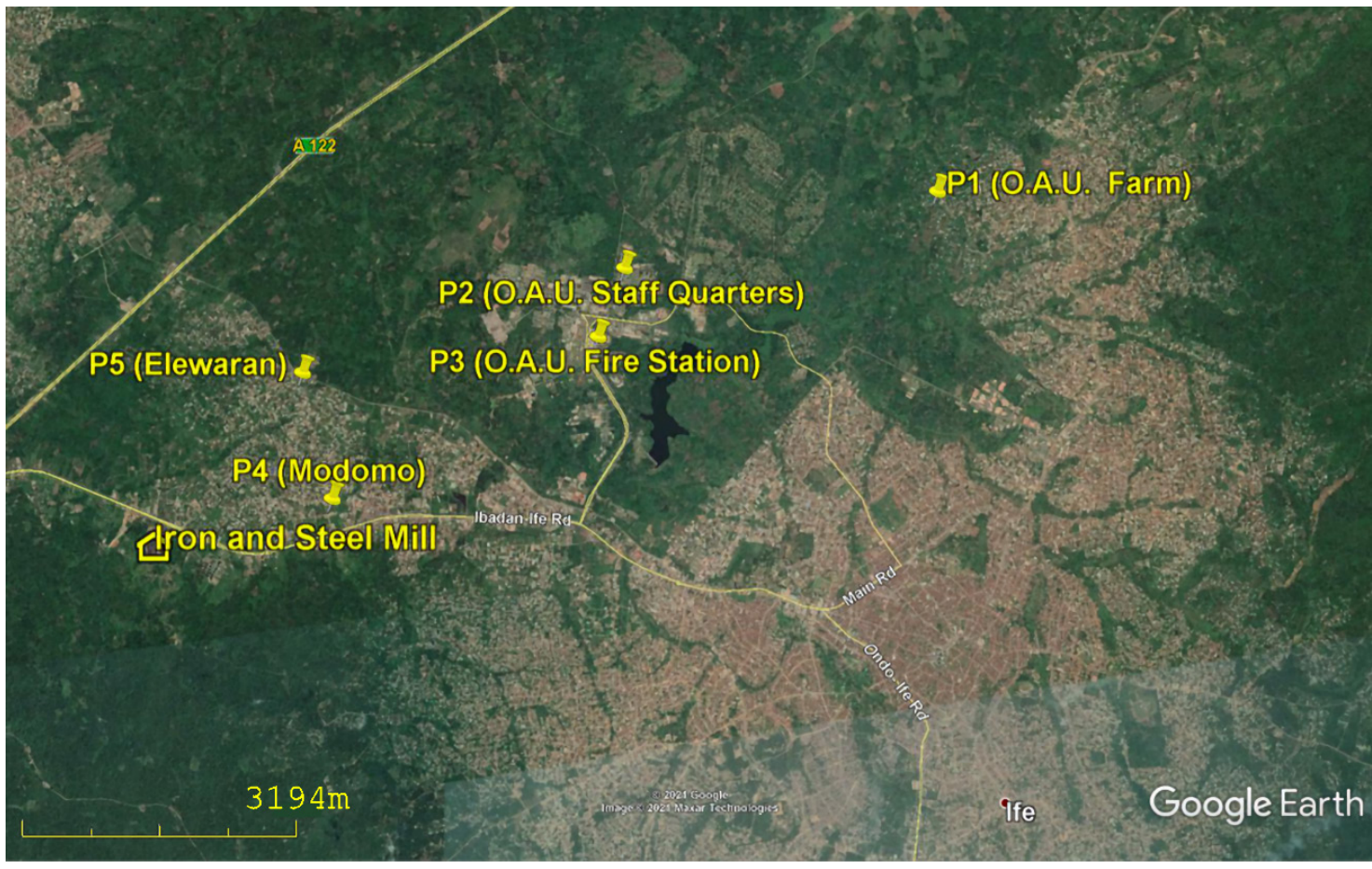

Fig. 1. Location of monitoring sites and the scrap iron and steel mill.

Table 1. Description of monitoring sites.

\begin{tabular}{|c|c|c|}
\hline Code & Sites & Site Description \\
\hline P1 & Teaching and Research Farm (OAUTRF) & $\begin{array}{l}\text { Within OAU farm and it is dedicated to agricultural activities including } \\
\text { planting and rearing of animals. }\end{array}$ \\
\hline P2 & Staff Quarters & $\begin{array}{l}\text { Within OAU Staff used residential area and close proximity to the } \\
\text { university waste dumpsite. }\end{array}$ \\
\hline P3 & Fire Service Station & $\begin{array}{l}\text { Within OAU campus area near the university main road and close } \\
\text { proximity to a bus station. }\end{array}$ \\
\hline P4 & Modomo & $\begin{array}{l}\text { Fast growing residential area, close to the main road and downwind of } \\
\text { iron and steel smelting factory. }\end{array}$ \\
\hline P5 & Eleweran & $\begin{array}{l}\text { Residential area further away from iron smelter and major road, closer } \\
\text { to a minor road. }\end{array}$ \\
\hline
\end{tabular}

sensor principles that sense selected toxic gases at the parts per-million-level in an environment. Each unit also has temperature and relative humidity $(\mathrm{RH})$ sensors as well as a 2-D sonic anemometer to measure wind speed and directions. Further details of the fundamental principles and operational procedures of the sensor and associated atmospheric variables sensors were given by Popoola (2012) and Popoola et al. $(2016,2018)$ for the gaseous sensors. The PM sensor has been evaluated by Sousan et al. (2016), Crilley et al. (2018), Chatzidiakou et al. (2019), and Li et al. (2020). Mead et al. (2013), Popoola et al. (2018) and Chatzidiakou et al. (2019) present extensive comparisons of these monitors to reference monitoring systems during field studies in the United Kingdom.

The major advantages of this sensor include low cost, low power use, high sensitivity, fast response, selectivity, multiple species monitoring, near real time measurement, and simple operating procedures (Popoola, 2012; Popoola et al., 2018). At each site, a box containing the sensor nodes were mounted at about $3 \mathrm{~m}$ above the ground on a $6 \mathrm{~m}$ pole and powered with a rechargeable battery. The low-cost sensors were operated simultaneously at the five sites for two months (June 8-July 30, 2018 in the wet season). The sensors recorded the gaseous and PM concentrations, and the meteorological variables every second and stores $20 \mathrm{~s}$ averages of these parameters. For the continuous measurements, the data were retrieved from a universal serial 
board (USB) stick every two weeks and then underwent further processing with suitable computer packages and software developed by the Department of Chemistry, University of Cambridge, UK. The PM mass concentrations and meteorological data were averaged to hourly values and further statistical analyses were performed using the Openair R software package (Carslaw, 2015; Carslaw and Ropkins, 2012) and SigmaPlot V14.

\subsection{Statistical Analysis}

The summary statistics were calculated. Normality was tested under the hypothesis: $\mathrm{H}_{\circ}$ : there is no normal distribution pattern with data obtained from the study area to determine to use either parametric or non-parametric methods. The confidence intervals for this study were set at $95 \%$ such that $p$-values $\leq 0.05$ resulted in the acceptance of the null hypothesis. The normality test was the Kolmogorov-Smirnov test. Spatial variations in the measured variables were assessed using the Kruskal-Wallis analysis of variance (ANOVA) on ranks (Kruskal and Wallis, 1952) with confidence level set at $95 \%$ under the hypothesis that there was spatial variation (median values were not equal) in pollutant concentrations and meteorological parameters observed across the monitoring sites. Dunn's method (Dunn, 1964) was used to compare the site to site (pairwise comparison) variation at a $95 \%$ confidence level.

\subsection{Source Directionality Using Conditional Bivariate Probability Function}

The directional dependence of local sources of PM affecting each sampling sites was explored with conditional probability function (CPF) embedded in a bivariate polar plot (BPP) using the conditional bivariate probability function (CBPF). Bivariate polar plots provide information on the potential source influences by wind speed and direction on the receptor site. The CBPF estimates the probability that high pollutant concentrations (above a predetermined threshold value) are associated with a given wind direction and speed (Kim et al., 2003; Uria-Tellaetxe and Carslaw, 2014; Sumesh et al., 2017). It is based on the ratio of the number of samples in a wind sector and wind speed interval with concentrations greater than the given threshold to the total number of samples in that sector and wind speed interval. The CBPF values were calculated using Eq. (1):

$\operatorname{CBPF}_{\Delta \theta, \Delta u}=\frac{m_{\Delta \theta, \Delta u \mid c>x}}{n_{\Delta \theta, \Delta u \mid}}$

where $m_{\Delta \theta, \Delta u}$ is the number of samples with wind direction from a given $\Delta \theta$ and wind speed interval in the interval of $\Delta u$ having a concentration $c$ greater than a threshold $x$ and $n_{\Delta \theta, \Delta u}$ is the total number of samples of that combination of wind speed and direction intervals $(\Delta u, \Delta \theta)$. In this study, $x$ was set at the $75^{\text {th }}$ percentile.

\subsection{Coefficient of Divergence}

Coefficient of divergence $(C O D)$ is a parameter used for the evaluation of degree of divergence of two datasets. This analysis was performed to understand the variability or degree of uniformity of pollutants species measured simultaneously in two sites during a specified period. The CoD was evaluated as follows:

$C o D_{j k}=\sqrt{\frac{1}{p} \sum_{i=1}^{p}\left(\frac{x_{i j}-x_{i k}}{x_{i j}+x_{i k}}\right)^{2}}$

where $\mathrm{j}$ and $\mathrm{k}$ represents the paired sampling sites; $x_{i j}$ and $x_{i k}$ stands for the average concentration for the same pollutants at the two sites and $\mathrm{p}$ is the number of pollutants under study. CoD is known to be self-normalizing and can be obtained from short and long-term averages (Wongphatarakul et al., 1998). CoD values range from zero to unity where values close to zero reveals strong similarity between the two sites while values close to unity depicts between the sites (Wongphatarakul et al., 1998; Liu et al., 2017). Wilson et al. (2005) reported that CoD values of 0.2 were consistent with spatial homogeneity of air pollutants. 


\subsection{Coefficient of Variation}

The Coefficient of Variation (CoV or r-squared) was also used to assess the spatial variation of pollutant species between sites. The $r$-squared values shows the variance of a pollutant in a site that can be explained by the pollutants at another site. Like CoD, r-squared values range from 01. The $r$-squared values greater or equal to 0.7 suggests strong similarity in the pollutant temporal variations between the compared sites while values closer to zero suggests significant difference in the pollutant variation between the sites.

\section{RESULTS AND DISCUSSION}

\subsection{Average Hourly Concentration of the Measured Pollutants}

The results of the average ( \pm standard deviation) of the concentration of the measured pollutants at the five sites are presented in Table 2. The maximum 1-hour average concentration for $\mathrm{PM}_{2.5}$ and $\mathrm{PM}_{10}$ are $36 \pm 1.5$ and $111 \pm 14 \mu \mathrm{g} \mathrm{m}^{-3}$ (P4), respectively. The high PM concentrations can be attributed to the location of this site in the fast-developing residential area with unpaved roads and a smelting industry. $\mathrm{PM}_{2.5} / \mathrm{PM}_{10}$ ratios have been used to aid source identification (Gogikar et al., 2018). In this study, moderate values of $\mathrm{PM}_{2.5} / \mathrm{PM}_{10}$ ratio were found at $\mathrm{P} 5, \mathrm{P} 2$, and $\mathrm{P} 4,(0.44$, 0.43 and 0.43 respectively) showing high anthropogenic contributions to the $P M$ concentrations at these sites likely including suspended dust from the roads. A previous study on the Obafemi Awolowo University campus using gravimetric methods reported daily mean $\mathrm{PM}_{2.5}$ and $\mathrm{PM}_{10}$ mass concentrations of $25.4 \pm 2.4$ and $37.2 \pm 32.4 \mu \mathrm{g} \mathrm{m}^{-3}$ (Owoade et al., 2012) were lower than the mass concentration obtained in this study, but with a much higher $\mathrm{PM}_{2.5} / \mathrm{PM}_{10}$ ratio. The daily average $\mathrm{PM}_{10}$ mass concentrations in this study exceeded the $50 \mu \mathrm{g} \mathrm{m}^{-3}$ limit value recommended by the WHO. Also, the daily average values of $\mathrm{PM}_{10}$ were 2.0, 1.8 and 1.6 times the threshold limit values of $50 \mu \mathrm{g} \mathrm{m}^{-3}$ stipulated by EU (2014) at P1, P4, and P3, respectively.

The maximum one-hour average $\mathrm{CO}$ concentration was $542 \mathrm{ppb}$ at P3 that was attributed to its proximity to a busy road. The vehicular emissions and other anthropogenic activities like cooking with solid fuels (Obaseki et al., 2017) contributed to the values observed at this site. NO maximum concentration of hourly average was $7.34 \mathrm{ppb}$ at site P3, similar to the value of CO. Ul-Haq et al. (2015) associated concentration of NO in cities to vehicular emission. The minimum average concentration of $\mathrm{CO}_{2}$ was found at P3 $(428 \mathrm{ppm})$ and the maximum was $471 \mathrm{ppm}$ at P4. The maximum hourly concentration of $\mathrm{NO}_{2}$ occurred at $\mathrm{P} 4(21.5 \mathrm{ppb})$, an area downwind of an industrial plume while the lowest concentration was found at the farm settlement (13.7 ppb). The highest ozone concentration was found at $\mathrm{P} 4(64.4 \mathrm{ppb})$. These results showed that maximum hourly-mean concentrations of $\mathrm{PM}_{2.5}, \mathrm{PM}_{10}, \mathrm{CO}_{2}, \mathrm{O}_{3}$ and $\mathrm{NO}_{2}$ were observed at $\mathrm{P} 4$, a fast-growing residential area and downwind of a smelting industry. The range of concentrations of $\mathrm{O}_{3}, \mathrm{NO}$ and $\mathrm{NO}_{2}$ observed in this study were similar to those reported by Hagenbjörk et al. (2017) at three different sites (regional, traffic and background) in Sweden.

Table 2. Descriptive statistics of hourly averages of measured pollutants.

\begin{tabular}{|c|c|c|c|c|c|c|c|c|c|}
\hline & Site & P1 & P2 & P3 & P4 & P5 & \multirow[b]{2}{*}{ WHO } & \multirow[b]{2}{*}{ EPA-NAAQS } & \multirow{2}{*}{ EU } \\
\hline & Averaging period & Mean \pm SE & Mean \pm SE & Mean \pm SE & Mean \pm SE & Mean \pm SE & & & \\
\hline $\mathrm{CO}^{*}$ & 1-hour & $393 \pm 69$ & $365 \pm 69$ & $542 \pm 200$ & $348 \pm 132$ & $404 \pm 121$ & & & \\
\hline $\mathrm{CO}_{2}{ }^{* *}$ & 1-hour & $465 \pm 39$ & $429 \pm 23$ & $428 \pm 22$ & $4713 \pm 37.9$ & $465 \pm 37$ & & & \\
\hline $\mathrm{NO}^{*}$ & 1-hour & $4.6 \pm 5.9$ & $6.5 \pm 5.9$ & $7.3 \pm 7.2$ & $7.2 \pm 7.1$ & $6.5 \pm 5.2$ & & & \\
\hline $\mathrm{NO}_{2}{ }^{*}$ & 1-hour & $13.7 \pm 5.9$ & $15.3 \pm 7.0$ & $19.8 \pm 7.6$ & $21.5 \pm 7.2$ & $17.5 \pm 6.0$ & & & \\
\hline $\mathrm{O}_{3}{ }^{*}$ & 1-hour & $58.8 \pm 5.4$ & $57.5 \pm 11.3$ & $63.7 \pm 10.9$ & $64.4 \pm 14.0$ & $59.4 \pm 12.1$ & & & \\
\hline $\mathrm{PM}_{2.5^{* * *}}$ & 1-hour & $35.1 \pm 1.2$ & $20.7 \pm 0.7$ & $31.4 \pm 1.0$ & $36.3 \pm 1.6$ & $21.0 \pm 1.0$ & & & 350 \\
\hline $\mathrm{PM}_{10}{ }^{* * *}$ & 1-hour & $103 \pm 5.5$ & $47.5 \pm 1.5$ & $80.4 \pm 2.4$ & $111 \pm 14$ & $50.3 \pm 3.5$ & & & \\
\hline $\mathrm{PM}_{2.5} / \mathrm{PM}_{10}$ & 1-hour & 0.37 & 0.43 & 0.37 & 0.43 & 0.44 & & & \\
\hline $\mathrm{PM}_{2.5}$ & 24-hour & $35.5 \pm 3.0$ & $21.0 \pm 1.3$ & $31.7 \pm 2.1$ & $36.5 \pm 3.7$ & $21.1 \pm 2.5$ & 25 & 35 & \\
\hline $\mathrm{PM}_{10}$ & 24-hour & $104 \pm 8.9$ & $47.8 \pm 2.4$ & $80.9 \pm 4.0$ & $109 \pm 26.5$ & $51.4 \pm 7.9$ & 50 & 150 & 50 \\
\hline $\mathrm{PM}_{2.5} / \mathrm{PM}_{10}$ & 24-hour & 0.37 & 0.44 & 0.39 & 0.43 & 0.44 & & & \\
\hline
\end{tabular}

${ }^{*} \mathrm{ppb} ;{ }^{* *} \mathrm{ppm} ;{ }^{* * *} \mu \mathrm{g} \mathrm{m}{ }^{-3}$. 


\subsection{Observed Meteorology during the Study Period}

The descriptive statistics for the meteorological variables (temperature, relative humidity and wind speed) at the five sites are presented in Table S1. Mean ( \pm SD) temperature across the sites ranged from $23.4 \pm 3.7^{\circ} \mathrm{C}(\mathrm{P} 2)$ to $25.6 \pm 3.2^{\circ} \mathrm{C}(\mathrm{P} 5)$. The Kruskal-Wallis test indicated a statistically significant differences $(p<0.05)$ in temperature across the sites except for P1/P3, P2/P3, and $\mathrm{P} 4 / \mathrm{P} 5$. The mean ( \pm SD) of hourly relative humidity ranged from $74.9 \pm 16.0 \%(\mathrm{P} 2)$ to $79.9 \pm 15.7 \%$ (P3). There was a statistically significant difference in the hourly average relative humidity observed across the monitoring sites $(p<0.05)$ except for P1/P5. The hourly averaged wind speed range across study sites was 0.05 to $2.48 \mathrm{~m} \mathrm{~s}^{-1}$. The Kruskal-Wallis analysis of the hourly mean wind speeds indicated statistically significant differences $(p<0.05)$ except P1/P2 and P3/P5. Given that these sites are in built areas, it is likely that local surface obstructions are diverting the wind and potentially reducing the observed speeds. Low wind speeds during calm period limit the dispersion of emissions within a locality leading to increased pollutant concentration (Dai et al., 2020).

The prevailing wind directions shown in Fig. S1 reflect winds primarily from the southwest with some northwesterly and limited southeasterly flows. Calm winds were observed about $16.7 \%$ of the time. There were prevailing low wind speeds that aided pollutant accumulation. It can be seen that there are some notable differences among the sites with P4 and P5 having northwesterly winds than at the other sites. P1/P2 and P1/P5 are the only pairs that have similar median directions.

\subsection{Spatial Variation of Pollutants}

The distributions of hourly-averaged concentration of the pollutants at the five monitoring sites are presented in Fig. 2 as box and whisker plots. The result showed the median (black line within the box), $25^{\text {th }}$ and $75^{\text {th }}$ percentiles of the pollutants. The lower and upper whiskers showed the minimum and maximum pollutant's concentration during the study. The results of the detailed statistical analyses are presented in Tables S1 and S2 of the Supplemental Information file. Those results are summarized in Table S3.

$\mathrm{CO}$ had the largest interquartile range and thus, its highest variation at site P3. Generally, there were significant differences in $\mathrm{CO}$ across all sites. This pattern could be attributed to a variety of activities including open burning and vehicular emissions. The highest concentrations of $\mathrm{CO}$ being at $\mathrm{P} 3$ could be attributed to its location near a bus park. For $\mathrm{CO}_{2}$, there were significant differences among most of the sites. However, P1/ P5 and P2/ P3 did not have significant differences. P1 is at the farm at one end of the domain while P5 is at the other end of the domain and is closest to the Iron and steel mill and in the residential district. P2 and P3 are quite close to one another with no significant sources that could affect these two sites differently.

There were significant differences in the variation of NO across most of the study area. However, the Dunn's result showed that there were again no statistically significant differences between the two sites within the university (P2 and P3). Similar periods of cooking and associated burning activities were likely to occur within the residential areas. Significant differences in the $\mathrm{O}_{3}$ and $\mathrm{NO}_{2}$ concentrations were also found across most of the sites. Sites $\mathrm{P} 1$ and $\mathrm{P} 2$ did not differ for either the $\mathrm{NO}_{2}$ or $\mathrm{O}_{3}$ medians. $\mathrm{O}_{3}$ medians did differ between P1/P5, P2/P4, and P2/P5. P4 and P5 are likely to be more highly affected by the major road south of the residential area, local combustion, and possibly emissions from the iron and steel mill.

There were also significant differences in $\mathrm{PM}_{2.5}$ and $\mathrm{PM}_{10}$ values across most of the study sites. Greater variability in the particulate matter fractions were observed at $\mathrm{P} 4$, a residential area with many unpaved roads and extensive two-wheel motor vehicle transport. For both fractions, it was observed that there were no significant differences observed between P1 and P3. P2 and P4 also had similar $\mathrm{PM}_{10}$ median values although $\mathrm{P} 4$ had a much greater range of values.

\subsection{Temporal Variation of Gaseous and Particulate Matter Pollutants}

\subsubsection{Diel variations}

The diel variations of $\mathrm{CO}$ concentration (Fig. 3) had two major peaks that occurred in the morning (06:00-08:00 hr) and at night (18:00-20:00 hr). The variation shown in the plots provides the $5^{\text {th }}$ and $95^{\text {th }}$ confidence intervals represented by the shaded areas. These times are 

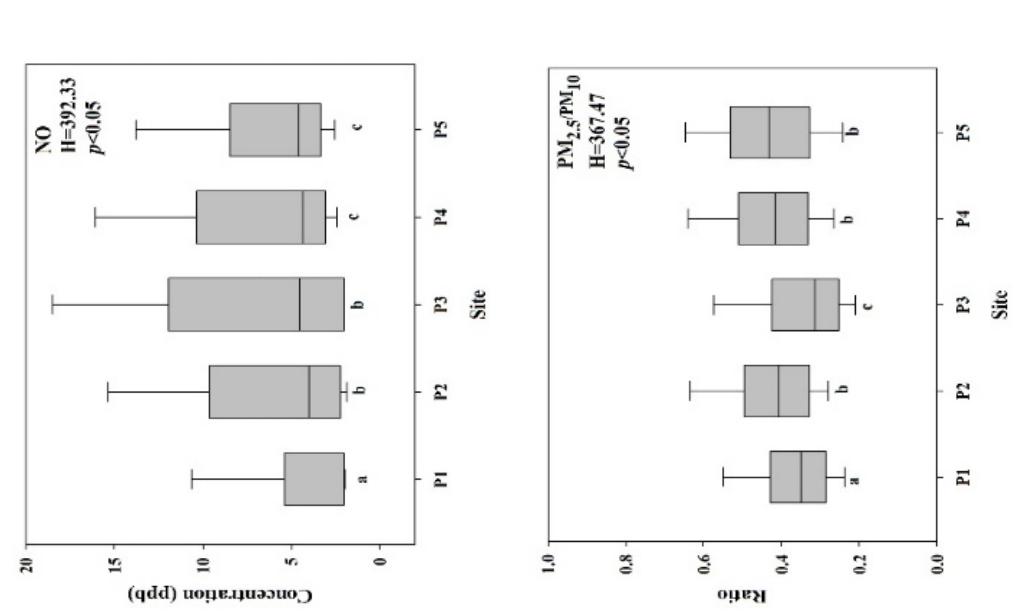

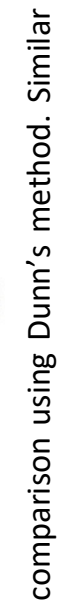
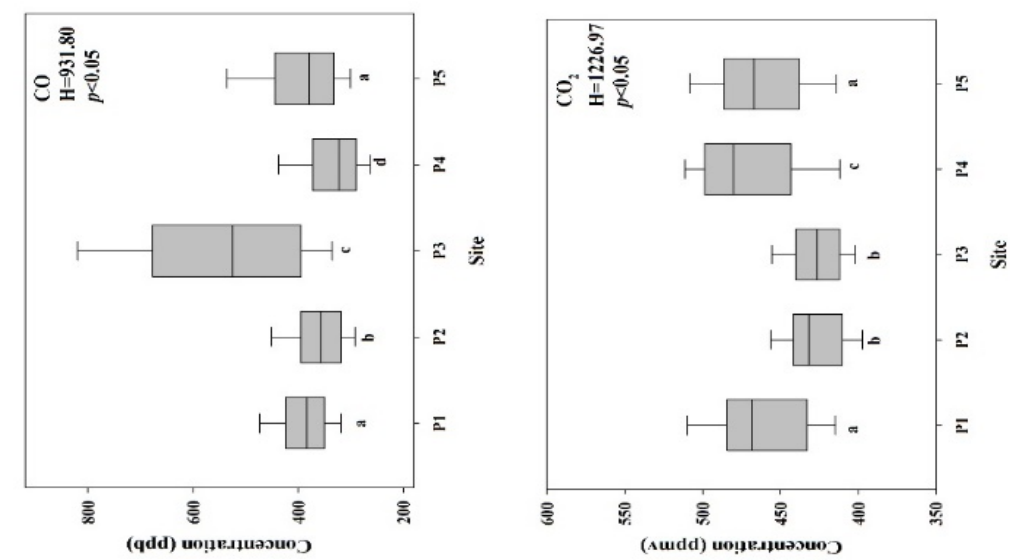

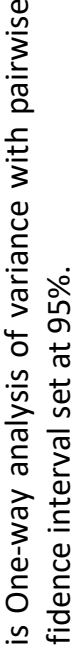
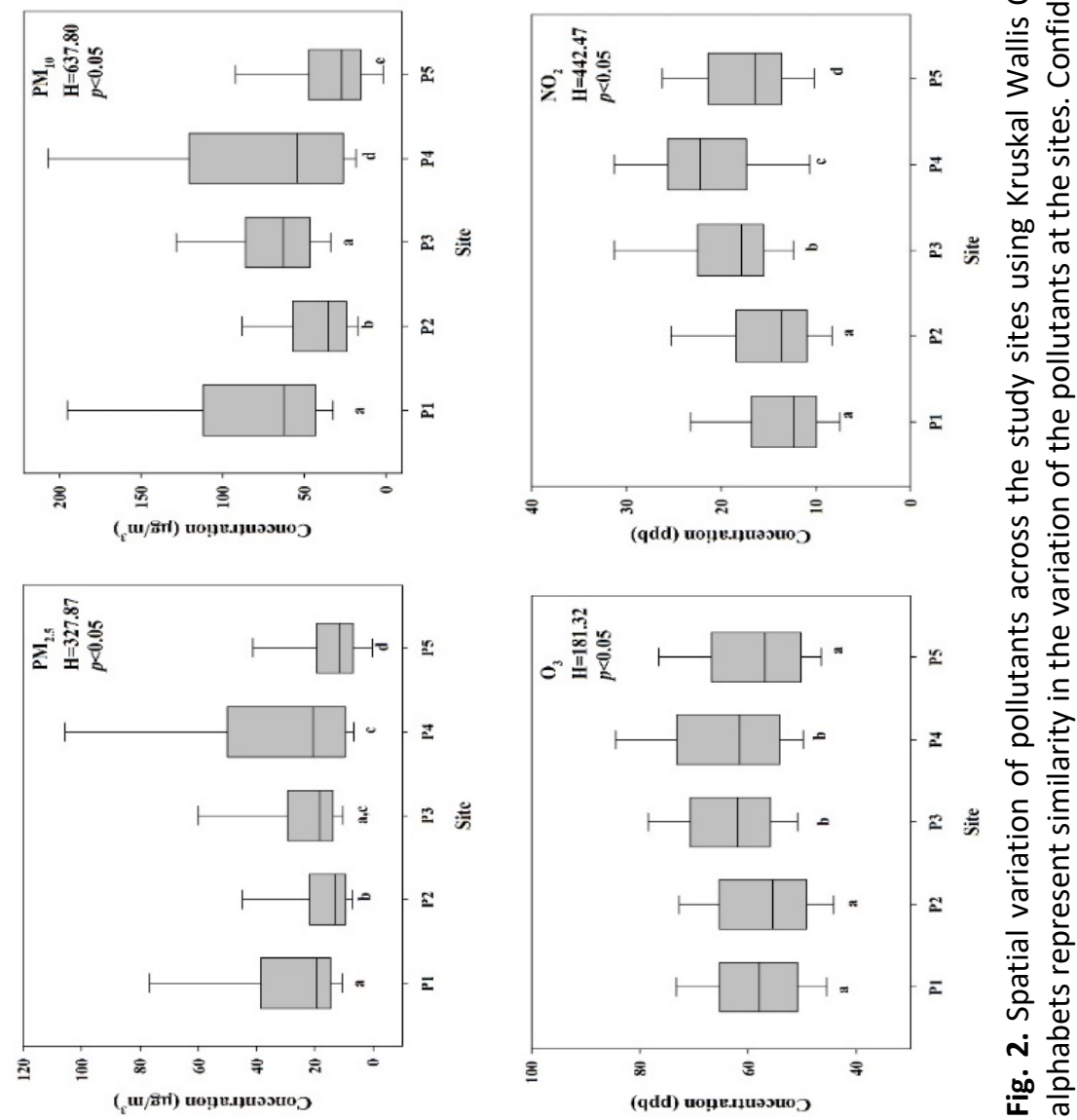

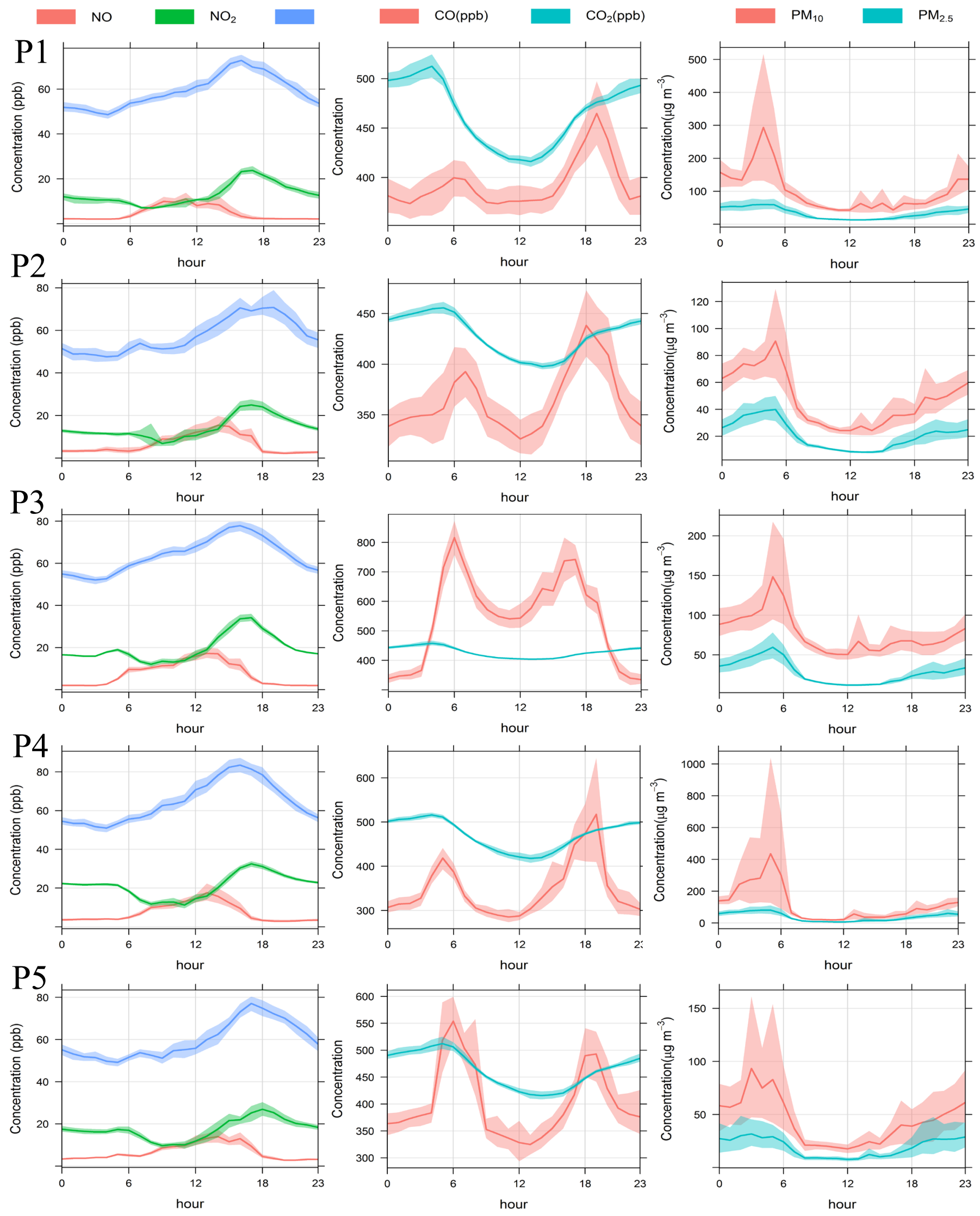

Fig. 3. Diel variation of $\mathrm{CO}(\mathrm{ppb}), \mathrm{CO}_{2}(\mathrm{ppm}), \mathrm{NO}(\mathrm{ppb}), \mathrm{NO}_{2}(\mathrm{ppb}), \mathrm{O}_{3}(\mathrm{ppb}), \mathrm{PM}_{2.5}\left(\mu \mathrm{g} \mathrm{m}^{-3}\right)$ and $\mathrm{PM}_{10}\left(\mu \mathrm{g} \mathrm{m}^{-3}\right)$ at $\mathrm{P} 1$ to $\mathrm{P} 5$. 
typically periods of higher traffic volumes (P3 and P5) while domestic combustion and electricity generators are mostly use at night at P2 and P4. Thus, these sources likely drive this observed variation. Higher morning peaks were observed at P3 and P5 while the higher peaks at the other locations (P1, P2, and P4) occurred in the evening. The diel variations of $\mathrm{CO}_{2}$ were similar across the study area. Boundary layer dynamics and source emission patterns are the major factors that influence the variability of $\mathrm{CO}_{2}$ concentration (Wang et al., 2010; Fang et al., 2016). The hourly peaks observed for $\mathrm{CO}$ and $\mathrm{CO}_{2}$ at all locations peaked in the evening when local biomass burning for cooking were likely driving the observed patters. There was a secondary CO peak in the morning likely from morning cooking.

The diel variations of $\mathrm{NO}, \mathrm{NO}_{2}$, and $\mathrm{O}_{3}$ (Fig. 3) at the monitoring sites were very similar to one another. There was an increase in NO from early morning 03:00 hr until 14:00-15:00 hr. NO peaked prior to the peak of $\mathrm{NO}_{2}$ and $\mathrm{O}_{3}$ which showed that photochemical transformation of $\mathrm{NO}$ through titration by ozone until the NO was sufficiently low that ozone concentrations could rise (Wang et al., 2018).

The similitude in the temporal variations can probably be attributed to general combustion (transport and residential combustion emissions) in the study area. The concentration of $\mathrm{NO}_{2}$ decreased during the convective hours (12:00-15:00 hr) of the day when mixing and secondary pollutant formation was maximal but dilution and vertical transport of primary pollutants predominated. The particulate matter fractions $\left(\mathrm{PM}_{2.5}\right.$ and $\left.\mathrm{PM}_{10}\right)$ showed similar diel variations (Fig. 3) at all stations with a major peak at 05:00-06:00 hr except at P5 that peaked earlier than the other stations. P4 and P5 are close to the iron and steel smelting factory where its major operations take place at night (6:00 pm-5:00 am). Unlike these sites, P4 and P5 had two peaks between midnight and 06:00 hr that could represent the time for batch processes of the factory's operation. Additionally, the $\mathrm{PM}_{2.5}$ and $\mathrm{PM}_{10}$ temporal variation in the study area can be assumed to be influenced by atmospheric dispersion playing significant role in transporting the pollutants from the source to the sites.

\subsection{Day of the Week Variation of Pollutants}

The day of week variations (Fig. S2) showed that CO exhibited similar daily variations at all locations. There were higher concentrations during the weekdays than on the weekends (Saturday and Sunday) for most sites. P3 showed the largest drop in CO concentration on weekends. This reduction was expected because it was close to a major university road that was used less on weekends. $\mathrm{CO}_{2}$ followed a similar variation pattern at all the monitoring stations. Unlike $\mathrm{CO}, \mathrm{CO}_{2}$ concentration increased on weekend days (Saturday and Sunday) compared to weekdays. This result may reflect people not working and thus present at their residences as well as additional cooking being done.

The daily concentration of $\mathrm{NO}_{2}$ ranged from 10 to $20 \mathrm{ppb}$ during the study and showed a uniform temporal variation at the sites. There were no differences in the day of week variations of $\mathrm{NO}$ and $\mathrm{O}_{3}$ at the monitoring sites. The day of week variations of $\mathrm{PM}_{2.5}$ and $\mathrm{PM}_{10}$ at the monitoring sites were similar. This result could be due to similar sources, largely transportation and the transport of particles from iron and steel smelting factory at few kilometres from the sites. For most of the sites, the highest PM concentrations were observed midweek (Tuesday and Wednesday).

\subsection{Source Identification and Characterization}

\subsubsection{Conditional bivariate probability plots}

Fig. 4 shows the CBPF results for CO. The residential area sites (P4 and P5) show opposite directions at relatively low wind speeds mostly under $2 \mathrm{~m} \mathrm{~s}^{-1}$ suggesting that local activities in this area are the primary sources. Given that the winds are generally from the southwest (Fig. S1), there is clearly substantial local emissions. These sources would include the minor road bordering the area and local combustion for cooking. P1 shows the highest probabilities in the southwesterly direction toward the campus area for wind speeds under $1.5 \mathrm{~m} \mathrm{~s}^{-1}$. P2 and P3 on the OAU campus again show preferred southerly directions. P2 appears to be seeing emissions from the road and the area around the Fire Station whereas P3 is affected by the campus area to the south southwest to the west southwest. 


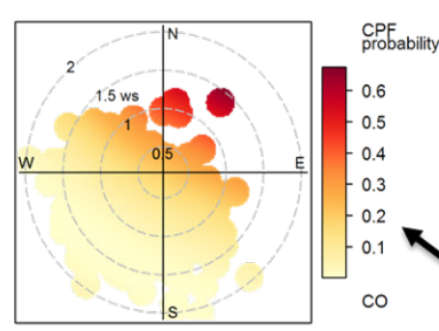

CPF at the 75 th percentile $(=442)$

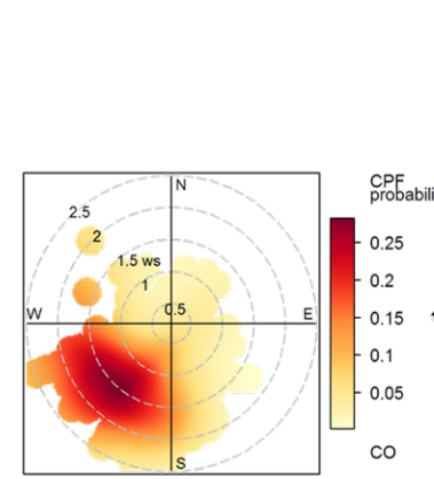

CPF at the 75th percentile $(=666)$

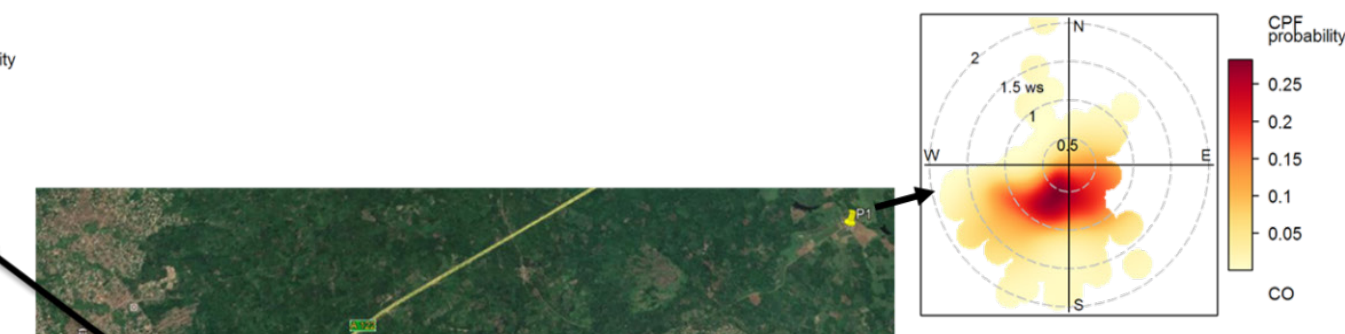

CPF at the 75 th percentile $(=424)$
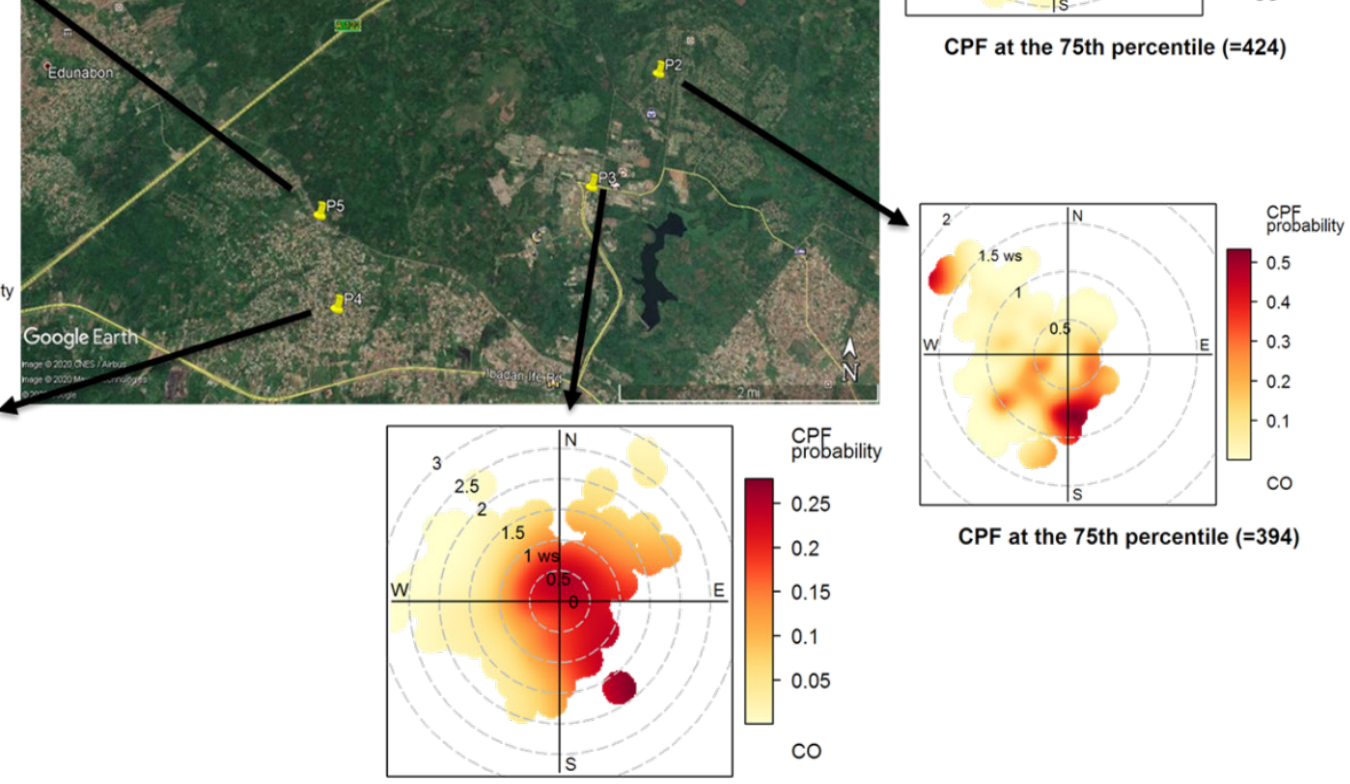

CPF at the 75 th percentile $(=394)$

CPF at the 75 th percentile $(=372)$

Fig. 4. Conditional Bivariate Probability Functions for $\mathrm{CO}(\mathrm{ppb})$ for sites P1-P5.

Fig. 5 presents the CBPF plots for $\mathrm{CO}_{2}$. They have very different patterns than those observed for $\mathrm{CO}$ with all of the higher probability areas appearing at higher wind speeds. There are much smaller relative variations in the $\mathrm{CO}_{2}$ concentrations since local emissions are superimposed on the $\sim 400 \mathrm{ppm}$ global background. P1 showed a strong influence to the southwest under higher wind speeds $\left(\sim 5 \mathrm{~m} \mathrm{~s}^{-1}\right)$, a lower probability area to the southeast under lower wind speeds, some influence from the north at speeds between 2.0 and $2.5 \mathrm{~m} \mathrm{~s}^{-1}$, and at very little low wind speed probabilities. Thus, there are none or very weak sources in the immediate vicinity of $\mathrm{P} 1$. There are large residential areas to the southwest to the southeast (city of Ife). Sources affecting P2 are on the OAU campus area to the west southwest. P3 shows a weaker influence from the campus area and a strong focused area to the east southeast. A large source is the Obafemi Awolowo University Teaching Hospitals Complex (OAUTHC) that is $4.8 \mathrm{~km}$ from P3 at $97.5^{\circ}$. They would be cooking using LPG as well as drawing considerable traffic in the area. Another smaller potential source is the Moremi High School is $2.5 \mathrm{~km}$ at $96.9^{\circ}$ from P3. However, there is no cooking done there and food is brought in as needed.

Figs. 6 and 7 show the CBPF plots for $\mathrm{PM}_{2.5}$ and $\mathrm{PM}_{10}$. All these plots show that the highest probabilities for high concentrations occur when wind speeds are low (typically $<1 \mathrm{~m} \mathrm{~s}^{-1}$ ). The P3 plot suggests influence from the road that curves around the Fire Station building. However, directionality is not well defined at low wind speeds. Thus, the differences in patterns observed between P2 and P3 may not be as substantial as it appears. The P4 plot suggests emissions in the residential area even with only weak flows from the westerly and northerly directions. The P5 plot also points to the residential area, but again all under low wind speed conditions. Neither the P4 or P5 plots suggest an effect of the iron and steel mill. The only obvious difference between the two size fraction plots is at $\mathrm{P} 3$ where the $\mathrm{PM}_{10}$ plot shows areas of influence to the northwest and east southeast at higher wind speeds.

The CBPF plots for $\mathrm{NO}, \mathrm{NO}_{2}$, and $\mathrm{O}_{3}$ are provided in Figs. S3-S5. There are notable differences between the $\mathrm{NO}$ and $\mathrm{NO}_{2}$ plots suggesting that $\mathrm{NO}$ is more local in origins while $\mathrm{NO}_{2}$ is 

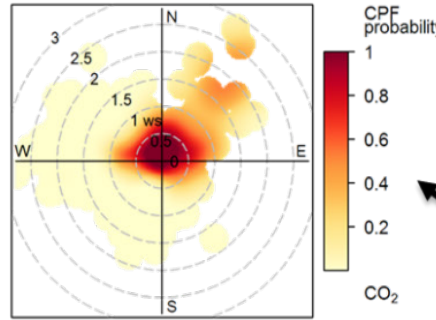

CPF at the 75 th percentile $(=499)$
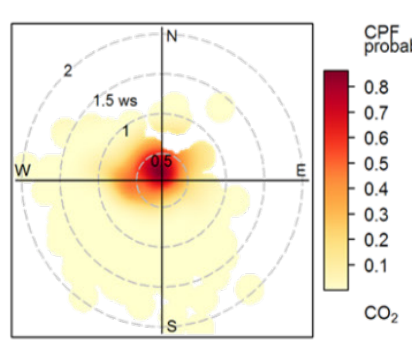

$\mathrm{CPF}$ at the 75 th percentile $(=486)$

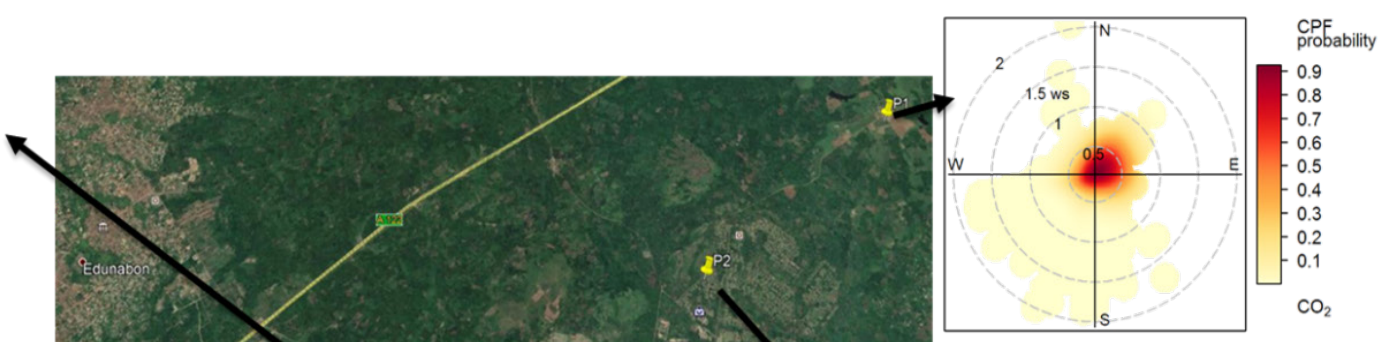

CPF at the 75 th percentile $(=484)$

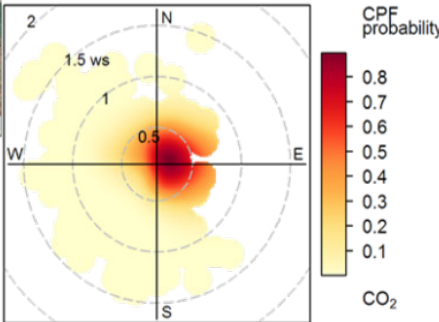

$\mathrm{CPF}$ at the 75 th percentile $(=442)$

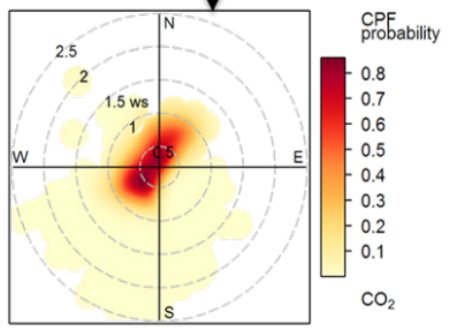

$\mathrm{CPF}$ at the 75 th percentile $(=440)$

Fig. 5. Conditional Bivariate Probability Functions for $\mathrm{CO}_{2}(\mathrm{ppm})$ at sites $\mathrm{P} 1-\mathrm{P} 5$.
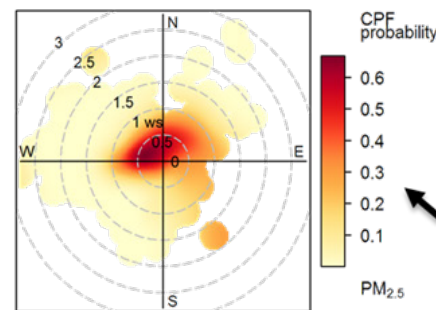

CPF at the 75 th percentile $(=46)$
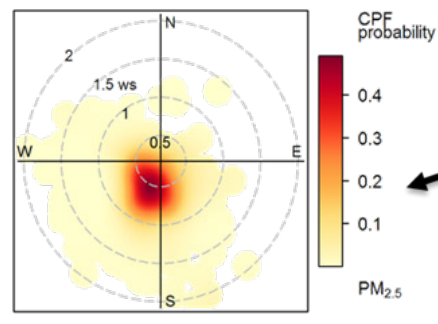

CPF at the 75 th percentile $(=19)$

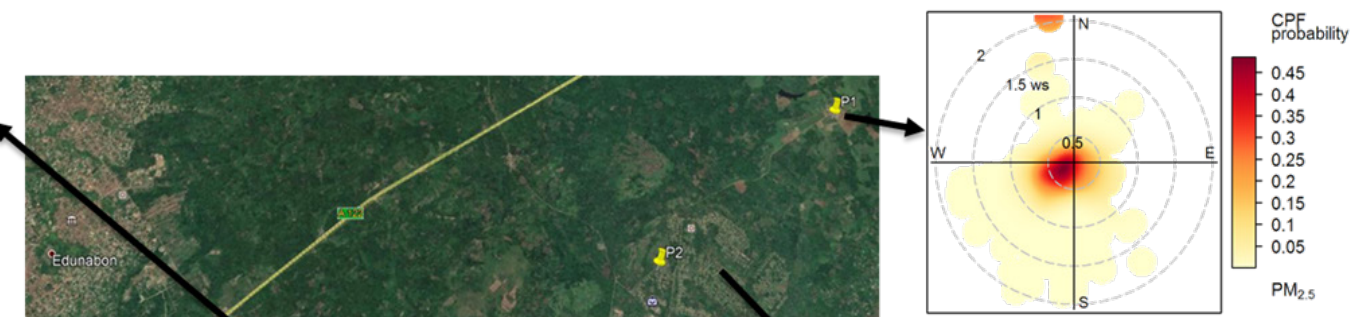

$\mathrm{CPF}$ at the 75 th percentile $(=37)$

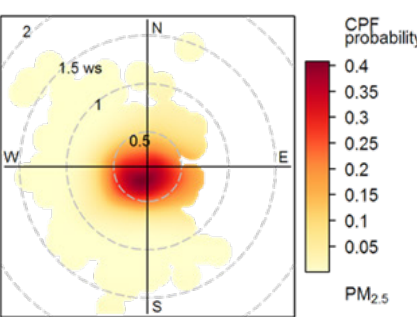

CPF at the 75 th percentile $(=22)$

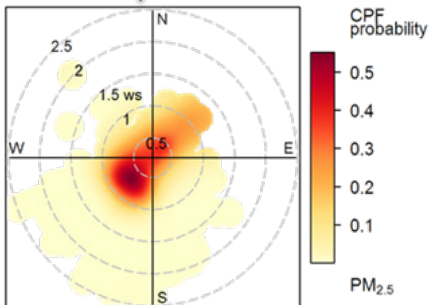

CPF at the 75 th percentile $(=29)$

Fig. 6. Conditional Bivariate Probability Functions for $\mathrm{PM}_{2.5}\left(\mu \mathrm{g} \mathrm{m}^{-3}\right)$ at sites P1-P5. 


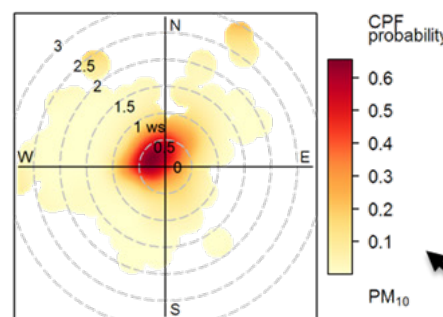

CPF at the 75 th percentile $(=113)$

$\mathrm{CPF}$ at the 75 th percentile $(=46)$

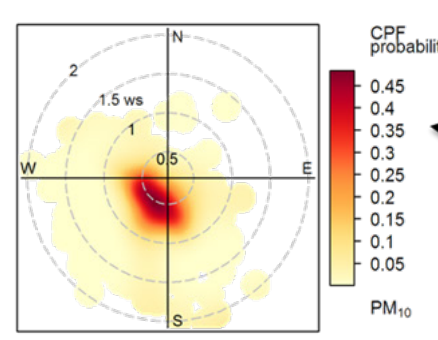

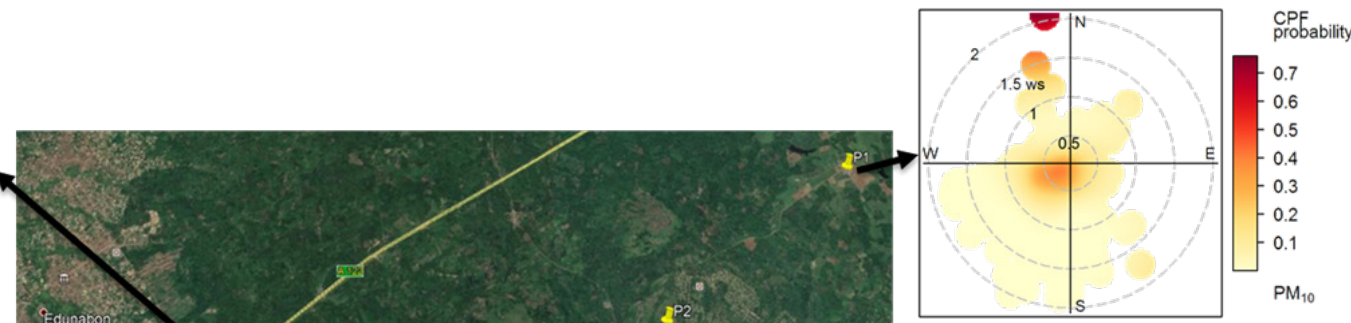

CPF at the 75 th percentile $(=106)$

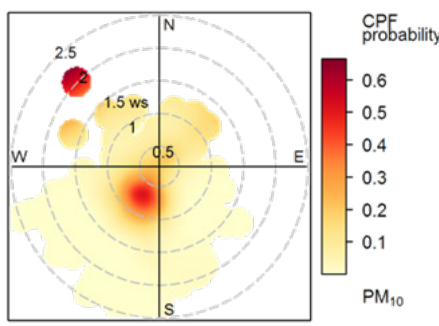

CPF at the 75 th percentile $(=86)$

Fig. 7. Conditional Bivariate Probability Functions for $\mathrm{PM}_{10}\left(\mu \mathrm{g} \mathrm{m}^{-3}\right)$ at sites $\mathrm{P} 1-\mathrm{P} 5$.

transported. At P4, there is a strong node to the SW at higher wind speeds that may reflect the high temperature combustion occurring at the iron and steel mill. The P2 plot shows a likely influence of combustion sources on the OAU campus such as cooking with LPG that did not affect P3. P3 again shows an NO area to the ESE (Fig. S4) similar to those seen in the $\mathrm{O}_{3}$ and $\mathrm{PM}_{10}$ plots at higher wind speeds suggesting a source that is likely to be the OAUTHC. Most of the high probability areas in the $\mathrm{NO}_{2}$ plots are at higher wind speeds around the outside of the plots similar to the $\mathrm{O}_{3}$ plots (Fig. S5). These patterns suggests that $\mathrm{NO}_{2}$ and $\mathrm{O}_{3}$ are likely in photolytic steady-state and then interact with the local NO emissions to reduce the ozone concentrations. However, the NO titration does not produce sufficient $\mathrm{NO}_{2}$ relative to the transported concentrations to produce high probabilities at low wind speeds (Wang et al., 2018).

\subsubsection{Coefficients of divergence}

The CoD values are presented in the Table 3. CoD values $<0.2$ are considered similar in concentration values (Wilson et al., 2005). The most similar sites were P2 and P5. These sites are the residential areas near a heavily travelled paved road. Overall, there were similarities among

Table 3. Coefficients of Divergence among the monitoring sites.

\begin{tabular}{llllll}
\hline Sites & P1 & P2 & P3 & P4 & P5 \\
\hline P1 & 0 & & & & \\
P2 & 0.18 & 0 & & & \\
P3 & 0.14 & 0.16 & 0 & 0 & \\
P4 & 0.33 & 0.37 & 0.33 & 0.36 & 0 \\
P5 & 0.18 & 0.04 & 0.13 & 0.36 \\
\hline
\end{tabular}

Significant values $(<0.20)$ are bolded. 
P1, P2, P3 and P5 compared with P4. P4 is characterized with unpaved roads and a dense residential population.

\subsubsection{Coefficients of variance}

The r-squared values are presented in Table 4. The variance of pollutants at most sites cannot be explained with by the same pollutant at the other sites except for $\mathrm{CO}_{2}$ at $\mathrm{P} 3$ and $\mathrm{P} 1$ which are locations within the university and presence of sources of combustion within close proximity. This variation could also be influenced by prevailing meteorology of the study sites.

\subsection{Limitations}

Due to limited availability of the monitoring equipment, this study was only conducted over a 2-month period during the later spring and early summer. Thus, it does not reflect seasonal variations in emission or meteorological conditions. Given differences in wind directions, precipitation, and human activities over an entire year, this work only provides a snapshot of this period.

Table 4. Spatial r-squared values among the measured pollutants.

\begin{tabular}{|c|c|c|c|c|c|}
\hline \multirow{2}{*}{ Pollutant } & \multicolumn{5}{|c|}{ Site } \\
\hline & & $\mathrm{P} 2$ & P3 & P4 & P5 \\
\hline \multirow[t]{5}{*}{$\mathrm{CO}$} & P1 & 0.008 & 0.067 & 0.004 & 0.000 \\
\hline & $\mathrm{P} 2$ & & 0.006 & 0.000 & 0.015 \\
\hline & P3 & & & 0.047 & 0.001 \\
\hline & P4 & & & & 0.017 \\
\hline & P5 & & & & \\
\hline \multirow[t]{5}{*}{ NO } & P1 & 0.238 & 0.468 & 0.325 & 0.115 \\
\hline & $\mathrm{P} 2$ & & 0.135 & 0.138 & 0.092 \\
\hline & P3 & & & 0.378 & 0.224 \\
\hline & P4 & & & & 0.178 \\
\hline & P5 & & & & \\
\hline \multirow[t]{5}{*}{$\mathrm{O}_{3}$} & P1 & 0.100 & 0.599 & 0.178 & 0.122 \\
\hline & $\mathrm{P} 2$ & & 0.040 & 0.221 & 0.216 \\
\hline & P3 & & & 0.220 & 0.028 \\
\hline & P4 & & & & 0.077 \\
\hline & P5 & & & & \\
\hline \multirow[t]{5}{*}{$\mathrm{NO}_{2}$} & P1 & 0.356 & 0.599 & 0.545 & NA \\
\hline & P2 & & 0.143 & 0.154 & 0.032 \\
\hline & P3 & & & 0.263 & 0.058 \\
\hline & P4 & & & & 0.285 \\
\hline & P5 & & & & \\
\hline \multirow[t]{5}{*}{$\mathrm{CO}_{2}$} & P1 & 0.354 & 0.757 & 0.551 & 0.284 \\
\hline & P2 & & 0.281 & 0.494 & 0.511 \\
\hline & P3 & & & 0.545 & 0.260 \\
\hline & P4 & & & & 0.355 \\
\hline & P5 & & & & \\
\hline \multirow[t]{5}{*}{$\mathrm{PM}_{25}$} & P1 & 0.109 & 0.350 & 0.158 & 0.004 \\
\hline & $\mathrm{P} 2$ & & 0.099 & 0.118 & 0.018 \\
\hline & P3 & & & 0.138 & 0.023 \\
\hline & P4 & & & & 0.108 \\
\hline & P5 & & & & \\
\hline \multirow[t]{5}{*}{$\mathrm{PM}_{10}$} & P1 & 0.150 & 0.260 & 0.151 & 0.009 \\
\hline & $\mathrm{P} 2$ & & 0.030 & 0.130 & 0.059 \\
\hline & P3 & & & 0.029 & 0.001 \\
\hline & P4 & & & & 0.114 \\
\hline & P5 & & & & \\
\hline
\end{tabular}




\section{CONCLUSIONS}

This study used low-cost sensor-based monitors to measure gaseous pollutants, PM, and meteorological variables within a fast-growing semi-urban settlement over a period of 8 weeks. The study found temporal and spatial variations of the pollutants across the study area. Wind in the study area had speeds from 0.5 to $2.5 \mathrm{~m} \mathrm{~s}^{-1}$ mostly from the southwest suggesting sources in the identified wind direction. The observed spatial variations for each pollutant were statistically significant at a $95 \%$ confidence level. The diel variations of pollutants revealed that $\mathrm{CO}, \mathrm{CO}_{2}, \mathrm{PM}_{2.5}$ and $\mathrm{PM}_{10}$ had two prominent peaks at morning and night times while $\mathrm{NO}, \mathrm{NO}_{2}$ and $\mathrm{O}_{3}$ were observed to peak between 12:00-15:00 hr. Average daily concentration showed that the all the pollutants peaked majorly during the weekdays (Tuesday or Wednesday) except $\mathrm{CO}_{2}$ that generally peaked on Sunday. Local sources such as heating/cooking and traffic were likely major sources as well as the scrap processing factory to the SW of the study area. The area is a fast-growing semi-urban settlement with increasing urban development. Thus, there is a need to implement mitigation strategies to reduce local emissions of pollutants. Also, limiting emission sources to the southwest of the study area such as from the scrap processing plant could lower the pollution load across the study area.

\section{SUPPLEMENTARY MATERIAL}

Supplementary material for this article can be found in the online version at https://doi. org/10.4209/aaqr.200598

\section{REFERENCES}

Carslaw, D.C. (2015). The openair manual-open-source tools for analysing air pollution data. Manual for version, 1, 1-4. https://davidcarslaw.com/project/openair/

Carslaw, D.C., Ropkins, K. (2012). openair - an R package for air quality data analysis. Environ. Modell. Software 27-28, 52-61. https://doi.org/10.1016/j.envsoft.2011.09.008

Chatzidiakou, L., Krause, A., Popoola, O.A.M., Di Antonio, A., Kellaway, M., Han, Y., Squires, F.A., Wang, T., Zhang, H., Wang, Q., Fan, Y., Chen, S., Hu, M., Quint, J.K., Barratt, B., Kelly, F.J., Zhu, T., Jones, R.L. (2019). Characterising low-cost sensors in highly portable platforms to quantify personal exposure in diverse environments. Atmos. Meas. Tech. 12, 4643-4657. https://doi.org/10.5194/amt-12-4643-2019

Cheng, I., Zhang, L., Blanchard, P., Dalziel, J., Tordon, R. (2013). Concentration-weighted trajectory approach to identifying potential sources of speciated atmospheric mercury at an urban coastal site in Nova Scotia, Canada. Atmos. Chem. Phys. 13, 6031-6048. https://doi.org/ 10.5194/acp-13-6031-2013

Crilley, L.R., Shaw, M., Pound, R., Kramer, L.J., Price, R., Young, S., Lewis, A.C., Pope, F.D. (2018). Evaluation of a low-cost optical particle counter (Alphasense OPC-N2) for ambient air monitoring. Atmos. Meas. Tech. 11, 709-720. https://doi.org/10.5194/amt-11-709-2018

Dai, Q., Liu, B., Bi, X., Wu, J., Liang, D., Zhang, Y., Feng, Y., Hopke, P.K. (2020). Dispersion normalized PMF provides insights into the significant changes in source contributions to $\mathrm{PM}_{2.5}$ after the COVID-19 outbreak. Environ. Sci. Technol. 54, 9917-9927. https://doi.org/10.1021/a cs.est.0c02776

Dockery, D.J., Pope, C.A. (1994). Acute respiratory effects of particulate in air pollution. Ann. Rev. Public Health 15, 107-132.

Dockery, D.W., Pope, C.A., Xu, X., Spengler, J.D., Ware, J.H., Fay, M.E., Ferris, B.G., Speizer, F.E. (1993). An Association between Air Pollution and Mortality in Six U.S. Cities. N. Engl. J. Med. 329, 1753-1759. https://doi.org/10.1056/NEJM199312093292401

Dunn, O.J. (1964). Multiple comparisons using rank sums. Technometrics 6, 241-252. https://doi.org/10.1080/00401706.1964.10490181

Falaiye, O.A., Yakubu, A.T., Aweda, F.O., Abimbola, O.J. (2013). Mineralogical characteristics of harmattan dust in Ilorin, Sub-sahara Africa. Ife J. Sci. 15, 175-181. https://doi.org/10.4314/ijs.v15i1 
Fang, S., Tans, P.P., Steinbacher, M., Zhou, L., Luan, T., Li, Z. (2016). Observation of atmospheric $\mathrm{CO}_{2}$ and $\mathrm{CO}$ at Shangri-La station: Results from the only regional station located at southwestern China. Tellus B 68, 28506. https://doi.org/10.3402/tellusb.v68.28506

Fawole, O., Olofinjana, B., Owoade, O. (2016). Compositional and Air-mass Trajectory Analysis of a Heavy Dust Episode (HDE) Aerosols in Ile-Ife, Nigeria. Br. J. Applied Sci. Technol. 13, 1-15. https://doi.org/10.9734/BJAST/2016/22331

Gogikar, P., Tyagi, B. (2016). Assessment of particulate matter variation during 2011-2015 over a tropical station Agra, India. Atmos. Environ. 147, 11-21. https://doi.org/10.1016/J.ATMOSEN V.2016.09.063

Gogikar, P., Tyagi, B., Padhan, R.R., Mahaling, M. (2018). Particulate matter assessment using in situ observations from 2009 to 2014 over an industrial region of eastern India. Earth Syst Environ 2, 305-322. https://doi.org/10.1007/s41748-018-0072-8

Guttikunda, S.K, Gurjar, B.R. (2012). Role of meteorology in seasonality of air pollution in megacity Delhi, India. Environ. Monit. Assess. 184, 3199-3211. https://doi.org/10.1007/s1066 1-011-2182-8

Hagenbjörk, A., Malmqvist, E., Mattisson, K., Sommar, N.J., Modig, L. (2017). The spatial variation of $\mathrm{O}_{3}, \mathrm{NO}, \mathrm{NO}_{2}$ and $\mathrm{NO}_{x}$ and the relation between them in two Swedish cities. Environ. Monitor. Assess. 189, 161. https://doi.org/10.1007/s10661-017-5872-z

Hu, Z., Tang, Z., Zheng, C., Guan, M., Shen, J. (2018). Spatial and temporal analyses of air pollutants and meteorological driving forces in Beijing-Tianjin-Hebei region, China. Environ. Earth Sci. 77, 540-559. https://doi.org/10.1007/s12665-018-7705-y

Jayamurugan, R., Kumaravel, B., Palanivelraja, S., Chockalingam, M.P. (2013). Influence of temperature, relative humidity and seasonal variability on ambient air quality in a coastal urban area. Int. J. Atmos. Sci. 2013, 264046. https://doi.org/10.1155/2013/264046

Karagulian, F., Barbiere, M., Kotsev, A., Spinelle, L., Gerboles, M., Lagler, F., Redon, N., Crunaire, S., Borowiak, A. (2019). Review of the performance of low-cost sensors for air quality monitoring. Atmosphere, 10, 506. https://doi.org/10.3390/atmos10090506

Khiem, M., Ooka, R., Hayami, H., Yoshikado, H., Huang, H., Kawamoto, Y. (2010). Process analysis of ozone formation under different weather conditions over the Kanto region of Japan using the MM5/CMAQ modelling system. Atmos. Environ. 44, 4463-4473. https://doi.org/10.1016/ j.atmosenv.2010.07.038

Kim, E., Hopke, P.K., Edgerton, E.S. (2003). Source identification of Atlanta aerosol by positive matrix factorization. J. Air Waste Manage. Assoc. 53, 731-739. https://doi.org/10.1080/10473 289.2003.10466209

Kruskal, W.H., Wallis, W.A. (1952). Use of ranks in one-criterion variance analysis. J. Amer. Stat. Assoc. 47, 583-621. https://doi.org/10.2307/2280779

Kumar, P., Morawska, L., Martani, C., Biskos, G., Neophytou, M., Di Sabatino, S., Bell, M., Norford, L., Britter, R. (2015). The rise of low-cost sensing for managing air pollution in cities. Environ. Int. 75, 199-205. https://doi.org/10.1016/j.envint.2014.11.019

Li, J., Mattewal, S.K., Patel, S., Biswas, P. (2020). Evaluation of nine low-cost-sensor-based particulate matter monitors. Aerosol Air Qual. Res. 20, 254-270. https://doi.org/10.4209/aaq r.2018.12.0485

Liu, Y., Yan, C., Ding, X., Wang, X., Fu, Q., Zhao, Q., Zhang, Y., Duan, Y., Qiu, X., Zheng, M. (2017). Sources and spatial distribution of particulate polycyclic aromatic hydrocarbons in Shanghai, China. Sci. Total Environ. 584, 307-317. https://doi.org/10.1016/j.scitotenv.2016.12.134

Manikonda, A., Zíková, N., Hopke, P.K., Ferro, A.R. (2016) Laboratory assessment of low-cost PM monitors, J. Aerosol Sci. 102, 29-40. https://doi.org/10.1016/j.jaerosci.2016.08.010

Masiol, M., Squizzato, S., Chalupa, D., Rich, D.W., Hopke, P.K. (2018) Evaluation and field calibration of a low-cost ozone monitor at a regulatory urban monitoring station. Aerosol Air Qual. Res 18, 2029-2037. https://doi.org/10.4209/aaqr.2018.02.0056

Mead, M.I., Popoola, O.A.M., Stewart, G.B., Landshoff, P., Calleja, M., Hayes, M., Baldovi, J.J., McLeod, M.W., Hodgson, T.F., Dicks, J., Lewis, A., Cohen, J., Baron, R., Saffell, J.R., Jones, R.L., (2013). The use of electrochemical sensors for monitoring urban air quality in low-cost, highdensity networks. Atmos. Environ. 70, 186-203. https://doi.org/10.1016/j.atmosenv.2012.11. 060

Mohsin, M., Abbas, Q., Zhang, J., Ikram, M., Iqbal, N. (2019). Integrated effect of energy 
consumption, economic development, and population growth on $\mathrm{CO}_{2}$ based environmental degradation: A case of transport sector. Environ. Sci. Pollut. Res. 26, 32824-32835. https://doi.org/10.1007/s11356-019-06372-8

Morais, S., Garcia e Costa, F., de Lourdes Pereira, M. (2012). Heavy Metals and Human Health. in: Oosthuizen, J. (Ed.), Environmental Health-Emerging Issues and Practice, Chapter 10. InTech, Rijeka, Croatia, pp. 227-272. https://doi.org/10.5772/29869

Obaseki, D.O., Awopeju, O.F., Awokola, B.I., Adeniyi, B.O., Adefuye, B.O., Ozoh, O.B., Isiguzo, G.C., Amusa, G.A., Adewole, O.O., Erhabor, G.E. (2017). Domestic solid fuel combustion in an adult population in Nigeria: A cross sectional analysis of association with respiratory symptoms, quality of life and lung function. Respir. Med. 130, 61-68. https://doi.org/10.1016/j.rmed.201 7.07.014

Ogundele, L.T., Owoade, O.K., Olise, F.S., Hopke, P.K. (2016). Source identification and apportionment of $\mathrm{PM}_{2.5}$ and $\mathrm{PM}_{2.5-10}$ in iron and steel scrap smelting factory environment using PMF, PCFA and UNMIX receptor models. Environ. Monit. Assess. 188, 574-594. https://doi.org/10.1007/s106 61-016-5585-8

Ogundele, L.T., Owoade, O.K., Hopke, P.K., Olise, F.S. (2017). Heavy metals in industrially emitted particulate matter in Ile-Ife, Nigeria, Environ. Res. 156, 320-325. https://doi.org/10.1016/j.en vres.2017.03.051

Omokungbe, O.R., Fawole, O.G., Owoade, O.K., Popoola, O.A.M., Jones, R.L., Olise, F.S., Ayoola, M.A., Abiodun, P.O., Toyeje, A.B., Olufemi, A.P., Sunmonu, L.A., Abiye, O.E. (2020). Analysis of the variability of airborne particulate matter with prevailing meteorological conditions across a semi-urban environment using a network of low-cost air quality sensors. Heliyon 6, e04207. https://doi.org/10.1016/j.heliyon.2020.e04207

Owoade, O.K., Olise, F.S., Ogundele, L.T., Fawole, O.G., Olaniyi, H.B. (2012). Correlation between particulate matter concentrations and meteorological parameters at a site in lle-Ife, Nigeria. Ife J. Sci. 14, 83-93. https://doi.org/10.4314/ijs.v14i1

Owoade, K.O., Hopke, P.K., Olise, F.S., Ogundele, L.T., Fawole, O.G., Olaniyi, B.H., Jegede, O.O., Ayoola, M.A., Bashiru, M.I. (2015). Chemical compositions and source identification of particulate matter $\left(\mathrm{PM}_{2.5}\right.$ and $\mathrm{PM}_{2.5-10}$ ) from a scrap iron and steel smelting industry along the Ife-Ibadan highway, Nigeria. Atmos. Pollut. Res. 6, 107-119. https://doi.org/10.5094/APR.201 5.013

Owoade, K.O., Hopke, P.K., Olise, F.S., Adewole, O.O., Ogundele, L.T., Fawole, O.G. (2016). Source apportionment analyses for fine ( $\left.\mathrm{PM}_{2.5}\right)$ and coarse (PM2.5-10) mode particulate matter (PM) measured in an urban area in southwestern Nigeria. Atmos. Pollut. Res. 7, 843-857. https://doi.org/10.1016/j.apr.2016.04.006

Pope, C.A. (2000). Epidemiology of fine particulate air pollution and human health: Biologic mechanisms and who is at risk. Environ. Health Perspect. 108, 713-723. https://doi.org/10.12 89/ehp.108-1637679

Popoola, O.A.M. (2012). Studies of urban air quality using electrochemical based sensor instruments, Doctoral dissertation, University of Cambridge. https://doi.org/10.17863/CAM.1 6288

Popoola, O.A.M., Stewart, G.B., Mead, M.I., Jones, R.L. (2016). Development of a baseline temperature correction methodology for electrochemical sensors and its implications for longterm stability. Atmos. Environ. 147, 330-343. https://doi.org/10.1016/j.atmosenv.2016.10.024

Popoola, O.A.M., Carruthers, D., Lad, C., Bright, V.B., Mead, M.I., Stettler, M.E.J., Saffell, J.R., Jones, R.L. (2018). Use of networks of low-cost air quality sensors to quantify air quality in urban settings. Atmos. Environ. 194, 58-70. https://doi.org/10.1016/j.atmosenv.2018.09.030

RStudio Team (2015). RStudio: Integrated Development for R. RStudio Inc., Boston MA. http://www.rstudio.com/

Seinfeld, J.H., Pandis, S.N. (2016). Atmospheric Chemistry and Physics: from Air Pollution to Climate Change, $3^{\text {rd }}$ Ed. John Wiley \& Sons, Hoboken, NJ.

Sousan, S., Koehler, K., Hallett, L., Peters, T.M. (2016). Evaluation of the Alphasense optical particle counter (OPC-N2) and the Grimm portable aerosol spectrometer (PAS-1.108). Aerosol Sci. Technol. 50, 1352-1365. https://doi.org/10.1080/02786826.2016.1232859

Sumesh, R.K., Rajeevan, K., Resmi, E.A., Unnikrishnan, C.K. (2017). Particulate matter concentrations in the southern tip of India: Temporal variation, meteorological influences, and source 
identification. Earth Syst. Environ. 1, 13-31. https://doi.org/10.1007/s41748-017-0015-9

Tian, G., Qiao, Z., Xu X. (2014). Characteristics of particulate matter (PM10) and its relationship with meteorological factors during 2001-2012 in Beijing. Environ. Pollut. 192, 266-274. https://doi.org/10.1016/j.envpol.2014.04.036

Ul-Haq, Z., Tariq, S., Rana, A. D., Ali, M., Mahmood, K., Shahid, P. (2015). Satellite remote sensing of total ozone column (TOC) over Pakistan and neighbouring regions. Int. J. Remote Sensing 36, 1038-1054. https://doi.org/10.1080/01431161.2015.1007255

Uria-Tellaetxe, I., Carslaw, D.C. (2014). Conditional bivariate probability function for source identification. Environ. Modell. Software 59, 1-9. https://doi.org/10.1016/j.envsoft.2014.05.002

Wang, L., Li, M., Yu, S., Yu, S., Chen, X., Li, Z., Zhang, Y., Jiang, L., Xia, Y., Li, J., Liu, W., Li, P., Lichtfouse, E., Rosenfeld, D., Seinfeld, J.H. (2020). Unexpected rise of ozone in urban and rural areas, and sulfur dioxide in rural areas during the coronavirus city lockdown in Hangzhou, China: Implications for air quality. Environ. Chem. Lett. 18, 1713-1723. https://doi.org/10.100 7/s10311-020-01028-3

Wang, Y., Munger, J.W., Xu, S., McElroy, M.B., Hao, J., Nielsen, C.P., Ma, H. (2010). $\mathrm{CO}_{2}$ and its correlation with $\mathrm{CO}$ at a rural site near Beijing: Implications for combustion efficiency in China. Atmos. Chem. Phys., 10, 8881-8897. https://doi.org/10.5194/acp-10-8881-2010

Wang, Y., Du, H., Xu, Y., Lu, D., Wang, X., Guo, Z. (2018). Temporal and spatial variation relationship and influence factors on surface urban heat island and ozone pollution in the Yangtze River Delta, China. Sci. Total Environ. 631, 921-933. https://doi.org/10.1016/j.scitote nv.2018.03.050

Wilson, J.G., Kingham, S., Pearce, J., Sturman, A. (2005). A review of intraurban variations in particulate air pollution: Implications for epidemiological research. Atmos. Environ. 39, 64446462. https://doi.org/10.1016/j.atmosenv.2005.07.030

Wongphatarakul, V., Friedlander, S.K., Pinto, J.P. (1998). A comparative study of PM2.5 ambient aerosol chemical databases. Environ. Sci. Technol. 32, 3926-3934. https://doi.org/10.1021/es 9800582

Yashiro, H., Sugawara, S., Sudo, K., Aoki, S., Nakazawa, T. (2009). Temporal and spatial variations of carbon monoxide over the western part of the Pacific Ocean, J. Geophys. Res. 114, D08305. https://doi.org/10.1029/2008JD010876

Zhang, Y., Jiang, W. (2018). Pollution characteristics and influencing factors of atmospheric particulate matter $\left(\mathrm{PM}_{2.5}\right)$ in Chang-Zhu-Tan area. IOP Conf. Ser.: Earth Environ. Sci. 108, 042047. https://doi.org/10.1088/1755-1315/108/4/042047

Zikova, N., Masiol, M., Chalupa, D.C., Rich, D.Q., Ferro, A.R., Hopke, P.K. (2017). Estimating hourly concentrations of $\mathrm{PM}_{2.5}$ across a metropolitan area using low-cost particle monitors. Sensors 17, 1922. https://doi.org/10.3390/s17081922 